\title{
Moving on: an archaeological record of mobility in the Esperance area of South-Western Australia
}

Moya Smith

Department of Anthropology, Western Australian Museum, Locked Bag 49, Welshpool DC, Western Australia, 6986, Australia.

\begin{abstract}
High residential mobility characterises the lifestyle of Aboriginal people of the Esperance area over the last 13,000 years. Despite environmental conditions and a resource structure in the coastal zone that would have sustained a less mobile lifestyle, the archaeological record in both coast and interior reflects a long-term commitment to moving on.
\end{abstract}

KEYWORDS: archaeology, prehistory, sites, resource structures

\section{INTRODUCTION}

Towards the end of the 1980s Sylvia Hallam was fond of telling those who asked about her profession, that she was a 'prehistoric archaeologist', enjoying the laughter that this elicited. However, pun aside, this does position Sylvia as an archaeologist whose vision was largely inspired by history, by the need to tell a story. While using the information that science could provide, at the same time she reflected the differences between an archaeology founded in history and an archaeology struggling either to define itself as science or to promote archaeological research as a scientific process (with an hypothesis, test, analysis and result). As one of the two pioneer archaeologists working in Western Australia from the early 1970s (the other being Charles Dortch), Sylvia Hallam encouraged generations of Western Australian students to embark on regional studies of pre-European Aboriginal societies and to tell the story of the human past in Western Australia. Explicitly or otherwise, Sylvia presented models that shaped the frameworks of decades of research. Her work continued to focus on a story, a sense of problem, rather than on the process of discovery.

Sylvia encouraged researchers to examine all available information that might inform the story of Aboriginal people's lives in pre-European Western Australia. Her students learnt to recognize the importance of re-examining primary excavation reports rather than relying only on latest reviews, to acknowledge the significance of landscape and resources and to extend their focus beyond individual sites. They also learnt to seek local cultural and environmental contexts, to value and use scientific evidence, to realise and exploit the potential value of historical and ethnographic records (Hallam 1975), and to understand the difference between the past and the histories that can be written about that past (Hexter 1971).

Sylvia's own regional prehistory of the Swan River area (e.g. Hallam 1983, 1986a) examined artefact distribution and promulgated models about the antiquity of occupation, definable phases of occupation history and population density. She drew the social framework for understanding the sites identified in the Swan Coastal Plain from analysis of ethnohistoric sources. From these she detailed subsistence patterns and social organisation, focusing on groupings, movements, aggregation, dispersal, and resource scheduling, recurrent or ephemeral occupation of different locations and movement between them. Thus people themselves were the primary players in these histories, whatever the impact on their lives of changing climate and resources. However, she never assumed that specific ethnohistoric or ethnographic data could be used to interpret archaeological data from any hunter-gatherer society in any geographic location. She constantly queried the apparent enthusiasm with which archaeologists applied such models across space and time. She insisted that at the very least it was important to consider the relevance of ethnohistoric data at a local level, before contemplating wider geographic or temporal application. Contemporary users of ethnohistoric data perhaps detail the limitations of its use more explicitly: 'The regional ethnohistoric record 
serves then as a source of territorial and economic modelling, rather than as an indicator of prehistoric behavioural patterns' (Dortch 2000: 17).

In 1986 Hallam could say that juxtaposing ethnohistoric data and archaeological materials was a rare phenomenon (Hallam 1986b). Perhaps inspired largely by the success of Hallam's own work, Western Australian students and heritage consultants have gone on to make this the standard in any field survey and analysis of archaeological materials. Indeed, her analysis of Aboriginal settlement patterns in the Swan Coastal Plain was a significant model for the work of several postgraduate archaeology students (Bird 1985; Ferguson 1985; Schwede 1990), including my own survey and analysis of archaeological sites in the Esperance area (Smith 1993). This followed Sylvia's example of detailing a story of a particular location, albeit a story with relevance for general questions in Australian archaeology.

\section{MAKING SENSE OF SITES INTHE ESPERANCE AREA}

The Esperance area is the most south-easterly territory identified in the 19th and 20th centuries as belonging to Nyungar speakers, who were part of the South-West culture bloc (Berndt 1979; Ferguson 1985: 27-80). I analysed data concerning 217 archaeological sites, 215 with artefacts, and an engraving site and an ochre quarry, from an area representing about $10 \%$ of the $9,500 \mathrm{~km}^{2}$ region bounded on the south-west by the coastal town of Esperance, Israelite Bay to the east, and Mt Ridley and Mt Ragged both some $80 \mathrm{~km}$ inland and to the north and north-east, respectively (Figure 1).

Most of the archaeological evidence from the

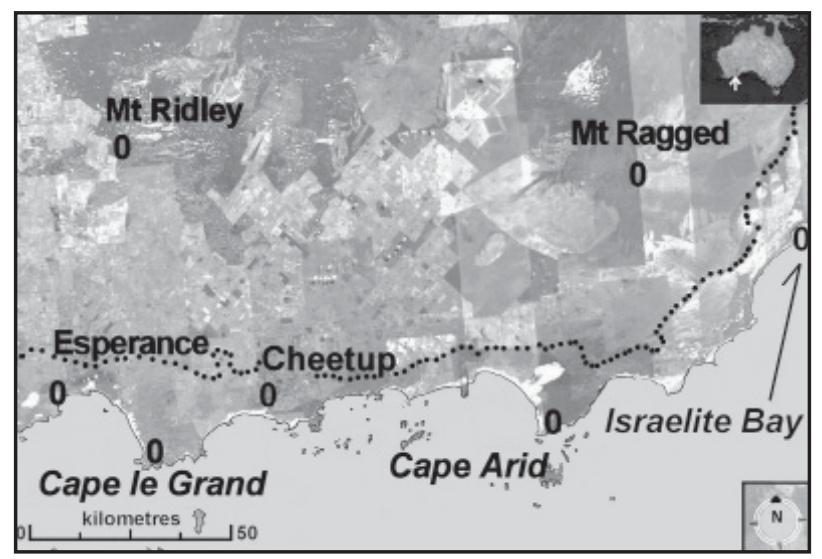

FIGURE 1
The Esperance area. The dotted line marks the approximate boundary between the coast and interior zones. Based on Google image, downloaded 27 October 2008.
Esperance area comprises scatters of stone artefacts, sometimes with additional features such as shell or other food refuse or tools, and constructed features or modified landscape elements. A primary quest in Australian archaeology has been to understand how such sites reflect the chronology of use of any given area (and sometimes the implications of this for a broader Australian past), the patterns of settlement, the population size of the area, and how these sites tie into behavioural theories either about the local area or about Australia or hunter-gatherer societies generally. The extent to which patterning across or between time periods can be analysed is frequently (Bowdler 2000), as in this region, severely constrained by the absence of either any, or tight, dating of sites.

My analysis was undertaken at a time when the relationship between peoples and the land in which they lived was still a popular paradigm in Australian prehistory (Huchet 1991). While my work has been undeniably underpinned by a cultural ecology framework, I sought to construct a regional prehistory and to address two demographic models that had held sway over understandings of the South-West's past. Where the regional prehistory was concerned I was keen to understand the differences between the earliest local evidence for human occupation of the region and that from other South-West locations on the west coast $(13,000 \mathrm{BP}$ locally compared with over 40,000 BP), differences in patterns of discarded artefacts between other SouthWest regions and the Esperance area, and whether the late 19th century socially marginal position of Esperance people in relationship to their neighbours, the remainder of the South-West bloc to the west and fringing desert to the north, was reflected in the chipped stone assemblages and other archaeological materials. I also explored the extent of evidence for either mid Holocene depopulation (Ferguson 1985) or late Holocene intensification (Lourandos 1983). My understandings of the region's past were further framed by ethnographic work with descendants of the people whose material I was studying and by the somewhat minimalist ethnohistoric accounts written by early settlers and explorers.

\section{THE ESPERANCE REGION - A MARGINAL ENVIRONMENT}

At the time of first European settlement, Esperance people's marginal position in terms of cultural groups was paralleled by the marginality of the region's resource reliability and predictability. The area lies not only on a socio-cultural boundary but also on the southern and eastern boundaries of biogeographic zones (e.g. the South-West botanical province) and straddles the boundary of the SouthWest drainage basin (Beard 1990 and Jarvis 1986 in Smith 1993: 13). Coastal parts of the region show 
remarkable predictability in rainfall, evaporation, temperature and prevailing wind direction, while the inland, sometimes a mere $10 \mathrm{~km}$ from the coast, has unpredictable characteristics similar to those of the neighbouring Nullarbor and arid zone to the east and north.

On the fringes of a classic Dry Mediterranean climate - with seasonal rainfall patterns, wet winters and predominantly dry summers - the annual rainfall along the coast averages $600-700 \mathrm{~mm}$ with an evaporation rate of $1,400-1,600 \mathrm{~mm}$. Inland the seasonal nature of rainfall is less marked, with sporadic summer thunderstorms providing most of the annual rainfall of $350-400 \mathrm{~mm}$. Here the annual evaporation rate is $2,000 \mathrm{~mm}$. Temperatures range from $-4^{\circ} \mathrm{C}$ to $47^{\circ} \mathrm{C}$. On the coast the average maximum temperature in the hottest months January and February is $26^{\circ} \mathrm{C}$, and average winter minimum between June and August is $8.5^{\circ} \mathrm{C}$. Inland the average summer maximum is $30^{\circ} \mathrm{C}$, and winter minimum $4.5^{\circ} \mathrm{C}$.

A proposed period of aridity and extensive dune building between 20,000 and 13,000 BP (Bowler 1976; Wyrwoll 1979) ends at the time of earliest known occupation of the Esperance area. At this stage, the coastline was about $80 \mathrm{~km}$ distant, $20 \mathrm{~km}$ closer than during the last glacial maximum. The exact nature of wind circulation and temperature variation is unclear but Beard (1973) may be correct in suggesting that rainfall curves probably paralleled the coast as they do now, and Recherche Archipelago Islands are the remnants of occupied wetter areas. Much of the current coast zone would have received reduced or less effective rainfall. By 9,000 years ago the coastline came within $5-10 \mathrm{~km}$ of its existing position. It is probable that the current coast and interior zones of the study area experienced aridity similar to the Eucla area and that, if not abandoned during the glacial maximum, the area was not densely occupied (Smith 1993: 37-38).

Locals would tell you that cool breezes - or howling gales - and cloudy weather are a consistent feature of the Esperance region. If similarly strong winds prevailed since first human occupation they must also have impacted on selection of camp site. During summer, breezes commonly come from the north-east in the morning, swinging round to southeast in the afternoon, and sometimes reaching speeds of up to $20 \mathrm{~km} / \mathrm{h}$. Throughout winter strong winds and gales come from an arc between north-west and south-west. By August and September the winds are re-established in the summer pattern, with morning westerlies and afternoon south-westerlies decreasing from the ferocity of the winter winds.

The landforms and underlying geological structures of the area constrain the time frame of the archaeological residue of settlement patterns. Short drainage channels dissect a narrow coastal plain about $10 \mathrm{~km}$ wide, exposing chert bearing Tertiary siltstones. The sandplain, inland from the coastal strip, is some $50 \mathrm{~m}$ higher than sea level and broken by small lakes and swamps in depressions. Low lying late Pleistocene and early Holocene long parallel sand dunes oriented west north-west cover much of the area, and clearly surface sites on the sandplain will date no earlier than this restricted period. More recent Holocene dunes are aligned south-west to north-east. These reflect dune mobilising winds from the south-west to the southeast. Current coastal drift dunes are produced by prevailing strong south-westerly winds. These dunes overly shallow clay beds, Eocene marine sediments comprising siltstone and patches of limestone, Proterozoic granite and gneissic migmatite headlands and domes, and bedded quartzites. The Eocene sediments, granites and quartzites also have surface exposures, the exposed Eocene sediments containing the chert that dominates local artefact assemblages. The most dramatic features of the landscape are the granites which feature as isolated hills or domes across the sandplain, few of these are higher than $100 \mathrm{~m}$.

\section{DATING SITES}

In the Esperance region, apart from three sites with any stratigraphy and dateable organic material, determination of antiquity of discarded materials and site occupancy, and the basis of discussion of variation in settlement patterning through time, was based on lithic materials and artefact types, as well as geological context of the discarded artefacts. There is a reasonably well established chronology for the appearance and disappearance of a specific lithic type in South-West assemblages. The sources of chert with inclusions of bryozoan fossils are considered to become inaccessible once sea levels reached their current height, around 6,000 years ago (Glover 1975a, 1975b; Ferguson 1980; Schwede 1990; Smith 1993; Dortch 2002), and even though people may have re-worked stone from earlier sites, large flakes of bryozoan chert can be considered earlier than middle Holocene (yes Sylvia, big is indeed older!). The presence (rather than absence) of elements of the Australian Small Tool Tradition (backed blades or backed flakes and adze slugs) reflect a discard or occupancy predominantly later than 6,000 years ago. Backed artefacts and adzes appear to become well established across Australia by around the mid Holocene (Bowdler and O'Connor 1991; Hiscock and Attenbrow 1998; Bowdler 2000), although the presence of backed artefacts is now attested as early as $8,380 \pm 20 \mathrm{BP}$ near Sydney (Hiscock and Attenbrow 1998) - these early dates bolstering the validity of a temporal link between a microlith from Northcliffe and material dated at 6,780 \pm 120 BP (SUA 379) (Dortch 1975). 


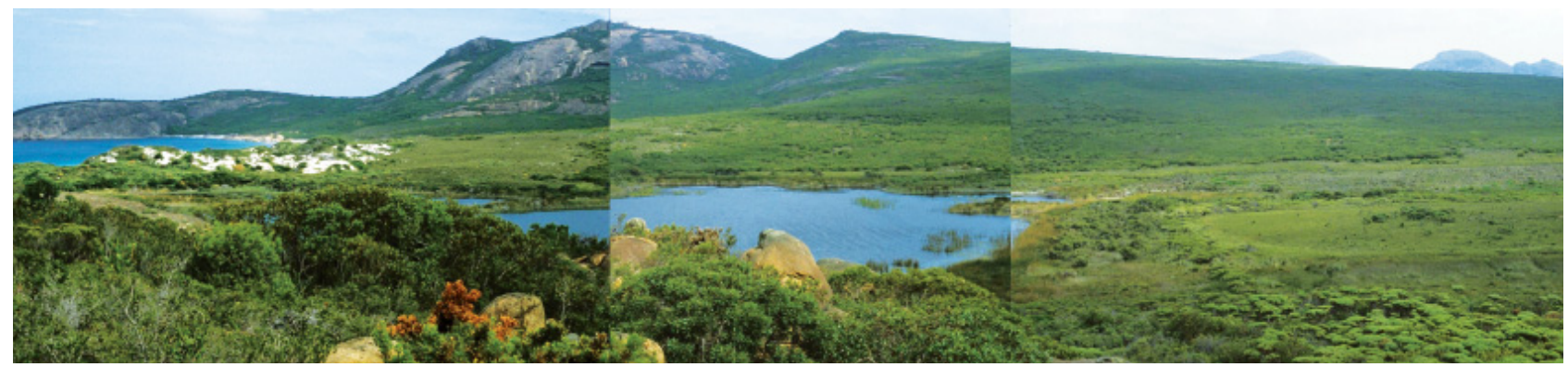

FIGURE 2 Coastal landscape near Cape le Grand.

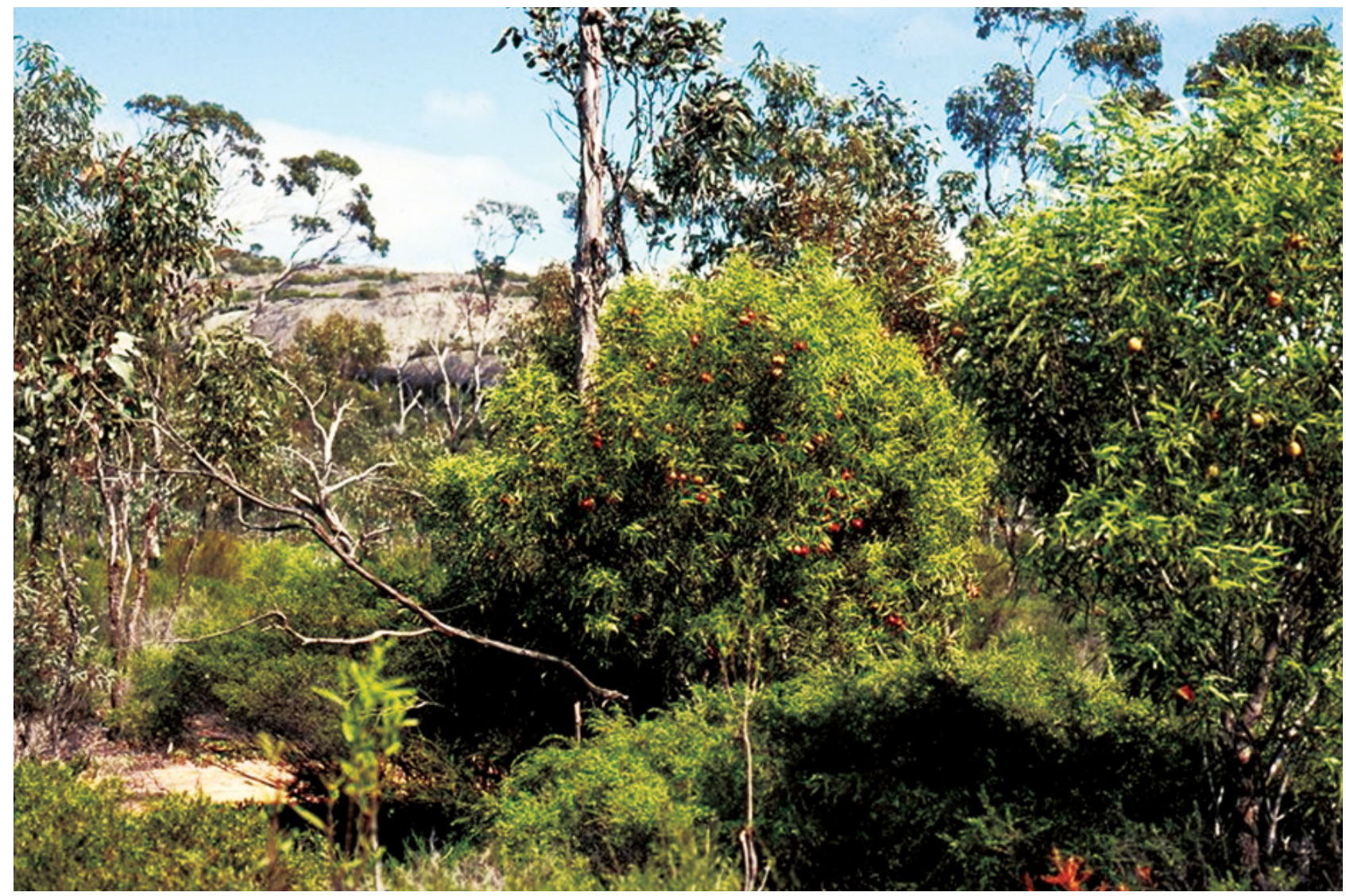

FIGURE $3 \quad$ Inland eucalypts and quandong, with Mount Ridley in the background.

Artefact scatters are located across the landscape, on or adjacent to granite domes or 'pavements', frequently with little to indicate precise chronology and frequently redeposited; in lunettes or fringing dunes around freshwater swamps or lakes; on dune crests; in blowouts or deflations in dunes; along creekbanks; in rockshelters and at stone sources. Vegetation patterns, underlying sediments and marked rainfall zones indicated a clear distinction between coast zone and interior or inland (Figure 1). The coast characteristically has scrub heath, coastal dune scrub, and mallee heath dominated by tallerack, a eucalypt (E. tetragona) that local people cited as the indicator of being in 'coast country' (Veth and Moore 1989; Mr T. Bullen pers. comm. 1991); with thickets of Melaleuca, Acacia or Banksia near swamps (Figure 2). Mallee, Allocasuarina thickets, and eucalypt woodlands dominate the inland, or interior, landscape (Figure 3).

\section{ASPECTS OF SPATIAL PATTERNING}

Dortch and Morse (1984) located 10 sites or clusters of stone artefacts on the granite islands of the Recherche Archipelago. Most of the material is thought to date from the period when the islands were hills in the extended coastal plain (i.e. before 
10,000 years ago), although it is possible that some artefacts were discarded by Aboriginal people working with sailors or whalers during the 1800s. Coastal sites are thought to demonstrate occupation after about 13,000 BP (the end of the Pleistocene dune building phase) though mostly between the mid Holocene and the historic period, and on the basis of landform and artefact typology interior sites do not appear to be earlier than mid Holocene.

There was clear variation in the distribution of sites in each of three zones - Recherche Archipelago Islands, the coastline and coastal plain and the less well watered interior. Analysis of environmental and internal site features, including site density, focus on specific topographic features, proximity to resources and aspect reflected further details of spatial patterning (Smith 1993: 283). From these data I constructed a model of resource structures and settlement pattern.

\section{SITE DENSITY}

In the Esperance region the average site density, or number of $\mathrm{km}^{2}$ per site, is one site per $4.4 \mathrm{~km}^{2}$ (including all sites) or one artefact scatter per $5 \mathrm{~km}^{2}$. This varies considerably from zone to zone, and according to topographic features on which sites are located, with the exception that site density on granites is fairly consistent irrespective of zone, and, apparently irrespective, of time of artefact discard. Site density on granites ranges from one site per 1.7 $\mathrm{km}^{2}$ on the islands, to one site per $2.1 \mathrm{~km}^{2}$ on the mainland. Esperance area sites exhibit the lowest site densities and smallest artefact assemblages so far known from the South-West region. Comparative site densities from the Fitzgerald River and King George Sound areas further west are shown in Table 1.

\section{SITE SIZE}

The majority (167 or $86 \%$ ) of the 193 artefact scatters recorded in the Esperance region have fewer than 351 artefacts including both debitage and formal tools (Table 2). Based on survey results, estimated flaked stone artefact populations for the entire 9,500 $\mathrm{km}^{2}$ region amount to approximately 360,000 and estimated numbers of sites to approximately 1,700. The overall pattern of site location identified so far suggests that more than one third of these would be in the coastal zone, which occupies approximately one quarter of the area.

These artefact numbers appear significantly lower than in either the southern west coast or the arid zone. Surface scatters at Ellenbrook, Quininup, and in the Perth metropolitan region have several thousand artefacts. In one $14 \mathrm{~km}^{2}$ area of the Swan Coastal Plain, Hallam (1983) has recorded 50,000 artefacts per square kilometre. In one part of the Arid Zone the majority of sites contain 5000 pieces or less ... [though] three sites contain over 100,000 pieces' (Veth 1989: 81).

\section{SPECIFIC TOPOGRAPHIC FEATURES}

The distribution of the small artefact scatters across the landscape is not random but tied to resource availability in the coastal and interior zones. Granite domes and granite flats are the focus of sites in all three zones. All island sites, and approximately $58 \%$ of both coastal and interior sites are on granites, while in terms of artefact numbers $67.9 \%$ of coastal artefacts and $75 \%$ of interior artefacts were discarded on these features. Remaining sites focus on different features in the mainland zones. In the coastal zone, swamps, rivers, lakes $(21 \%)$ and dunes $(20.3 \%)$ are the other foci of sites, while, in the interior, other sites focus on salt lakes $(26 \%)$ and areas of the sandplain (14\%). Probable reasons for the favoured status of granites include: the diversity of associated vegetation including documented food sources; ease of access to shelter from wind, rain and sun; convenience as look-out posts to monitor resources or other people; proximity to other resource zones; and the water catchment properties of granites

\section{PROXIMITY TO RESOURCES}

Proximity to freshwater sources appears to have been of paramount importance in selection of site locations. Granites act as water catchments and in addition have water retaining crevices, fissures and rockholes, and drainage from them feeds water into adjacent swamps or lakes. Swamps, lakes, rivers and salt lakes are likely to have been the locations of soaks. Exact locations of soaks cannot be identified, but gnamma holes, many with capstones (Figure 4),

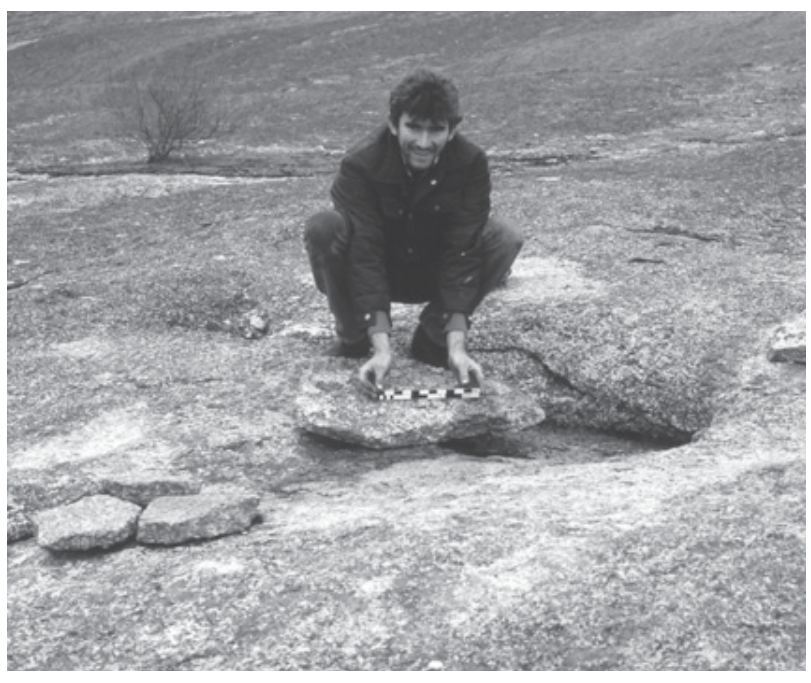

FIGURE 4
Capped gnamma hole, on a granite dome north of Cape Arid, interior zone. 

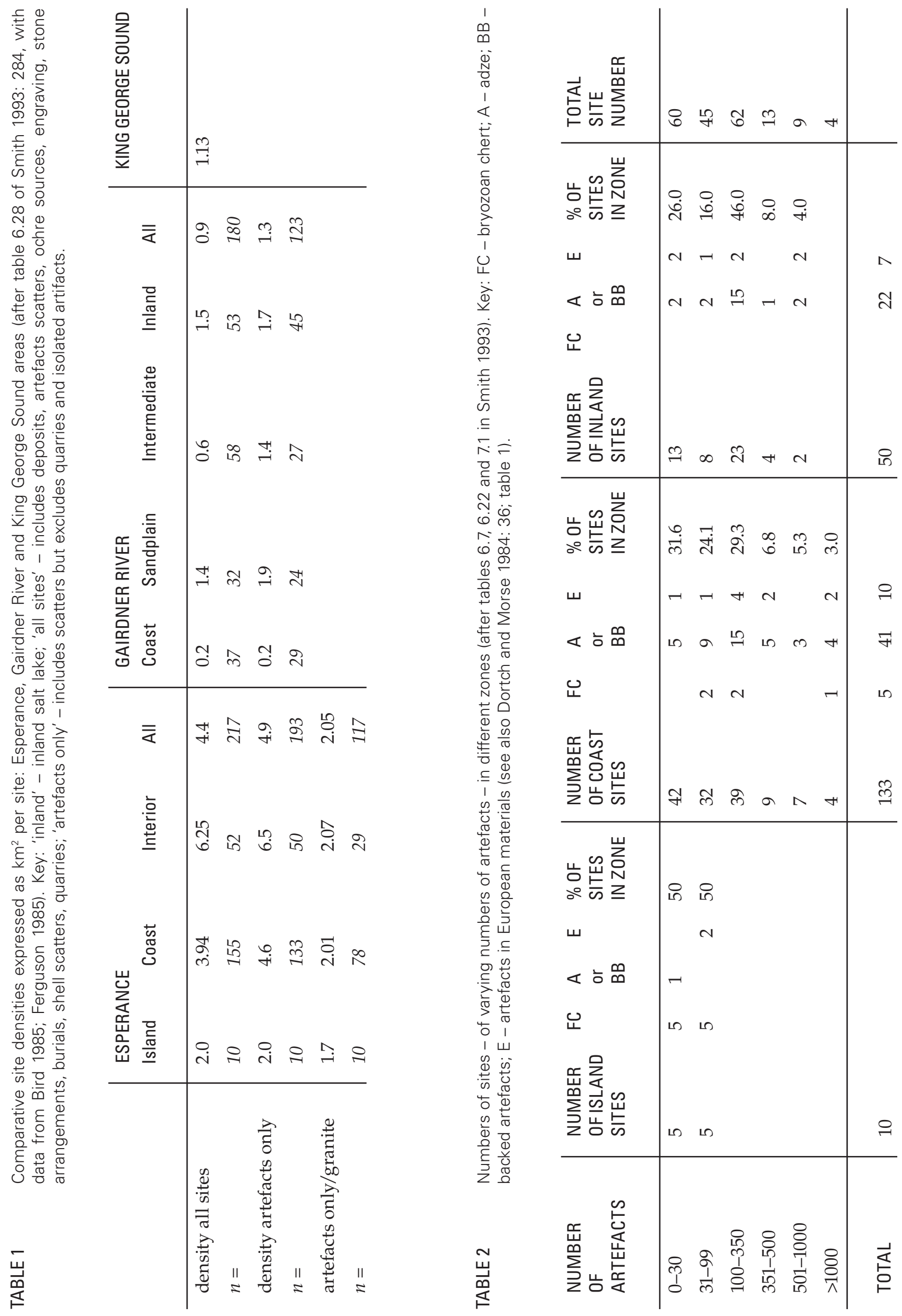


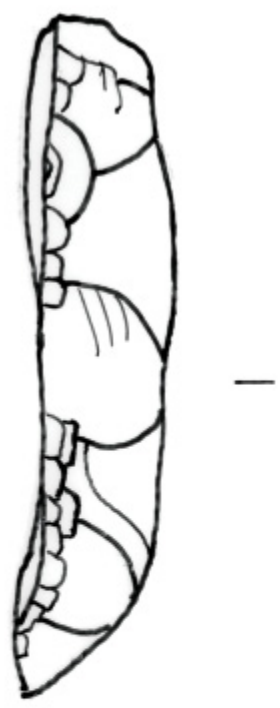

1a
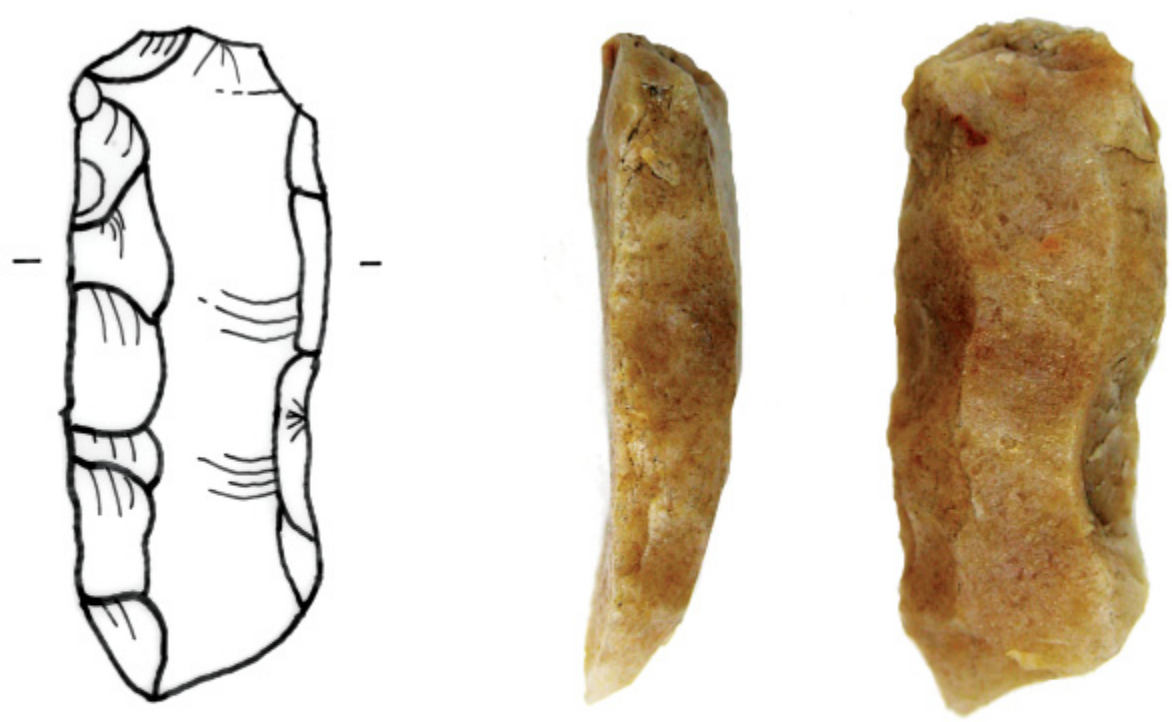

$1 \mathrm{~b}$
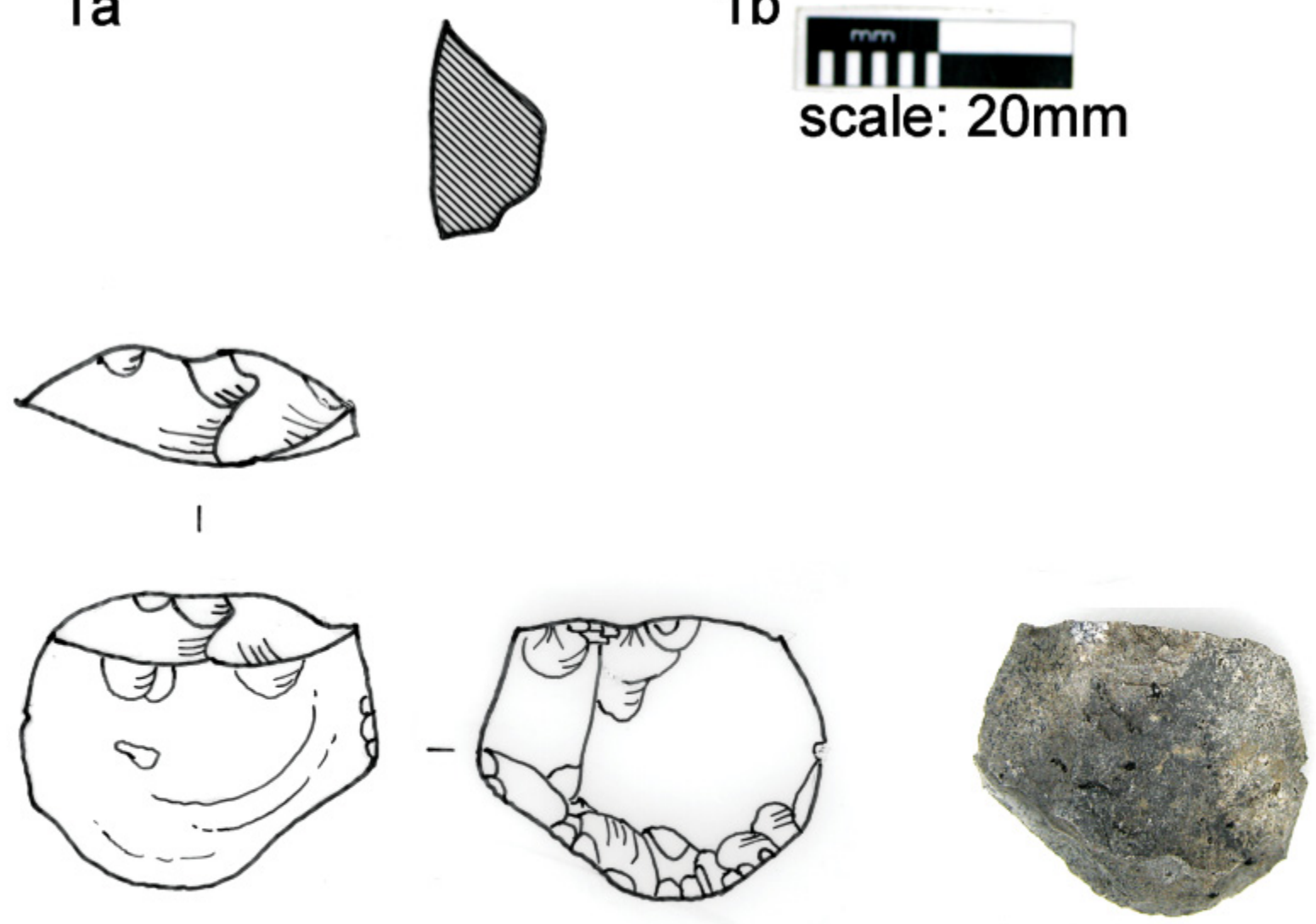

$2 a$

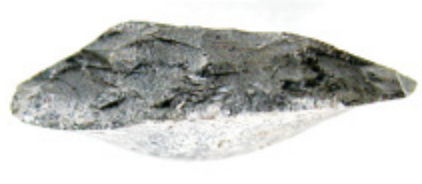


have been located on 24 sites, and artefact scatters are usually within $100 \mathrm{~m}$ of these. These favoured site locations not only offer fresh water, they also have vegetation communities which include exploited edible plant species. The predictability of the availability of these plants is tied directly to the reliability of the water.

Proximity to other resource zones is not an obvious factor in selection of camp site locations, although this must have affected population and residential mobility (especially given site size). Maximum optimal foraging range appears to lie within 5-10 km (Smith 1993: figure 6.10). At this distance, the majority of coastal sites have access to seven different resource zones, while most interior sites have access to four or five different zones. It is apparent that while increased foraging range in the interior gave access to more resource zone variation, people chose to move residence closer to these resources rather than foraging more widely from a base camp (logistical mobility) (cf. Kelly 1983, 1995).

Current studies of the role of technological organisation in lithic assemblages consider the links between 'how technological strategies are responsive to environmental factors and social/economic strategies. Proximity to the location of the knappable raw material sources is determined by the group's settlement pattern (Nelson 1991).' In the Esperance region, flakeable stone is perhaps one of the least difficult resources for people to have accessed at any stage during the human past. Reasonable quality chert is available almost the entire length of the coastline, in exposed surfaces of Tertiary sediments, while vein quartz, the other dominant lithic type, occurs in seams in the granites. Spicular coastal chert is clearly the preferred material, its widespread occurrence, the ease with which it can be extracted and its fracturing and cutting properties perhaps all contributed to its being the material of choice rather than other available materials such as quartz, silcrete and quartzite. There is, however, no simple linear relationship between dominant lithic material and source proximity. Where a material other than chert dominates an assemblage the choice of quartz appears in one instance to reflect a preferential use of quartz, perhaps for skin working, and in another, use of quartz after poor knapping led to the abandonment of a large chert core (Smith 1993: 318). Unlike the Jerramungup region to the west where chert was clearly of sufficient value for local people to practice a range of conservation strategies (Bird 1985: 281) such strategies are absent in the Esperance area. Not even 'exotic' raw materials derived from outside the region are curated.

\section{ASPECT AND OUTLOOK}

Resource proximity is not the only physical factor affecting site location. Within specific topographic features, there is marked patterning in relationship to aspect and outlook. In the coast zone, $78 \%$ of sites are positioned to maximise shelter from the south-west. All but one site of the remaining $22 \%$ have almost $360^{\circ}$ views. In the interior, $52 \%$ of sites are positioned to maximise shelter from the south-west, while $46 \%$ have $360^{\circ}$ views. The coastal emphasis on facing away from the south-west is echoed c. $275 \mathrm{~km}$ west in the Gairdner River region (Bird 1985: 156), which is also subject to the adverse climatic conditions which affect the Esperance coastline. The sweeping $360^{\circ}$ views are not paralleled west of the Esperance area and it is noteworthy that these are more common in the interior. In both zones approximately $50 \%$ of sites with $360^{\circ}$ views are on granites.

One important reason for this pattern is resource monitoring, not only of the immediate vicinity, but also noting rainfall distribution over the landscape, which has widespread implications for resource scheduling decisions. One of the key characteristics of the interior is the unpredictability of its rainfall, and thus of plant and animal foods. From the vantage point of the tops of granites, rainfall distribution and the consequent distribution of plant and animal foods as well as water sources, can be pinpointed with a reasonable degree of accuracy over large areas of land from the coast to well into the interior (and vice versa) (cf. Stafford et al. 1990). Since neither zone in isolation contains the resources necessary to sustain a viable economy, it is essential to monitor the entire landscape. The view from the granites gives knowledge of the macrocosm.

\section{CULTURAL AFFINITIES}

Local flaked stone assemblages demonstrate a reasonable degree of uniformity, with few diagnostic tools. In this they closely resemble other South-West assemblages. The large arid zone tula adzes (Hiscock and Veth 1991) are absent, and the adzes that occur are very similar to those from assemblages at King George Sound (Ferguson 1985: 371). There are small tula-shaped adzes which have evidence of resin on their proximal margins, and other more frequently occurring adzes without the pronounced striking platform and bulbar surface are retouched on lateral margins and also bear evidence of hafting (Figure 5). Backed pieces are small, and exhibit the range of shapes and sizes recorded at Jerramungup (Bird 1985: 210-211). Some of these have edge wear on their chords, and there is one partially backed flake from Cheetup with resin adhering to the retouched 'back'. There are many small flakes and chips (nearly all of coastal chert) with traces of resin in a position that would indicate that they had been hafted either in a taap (knife) or spear. The resin on all stone tools from the Esperance area appears to be Xanthorrhoea sp. which is more commonly the hafting cement 

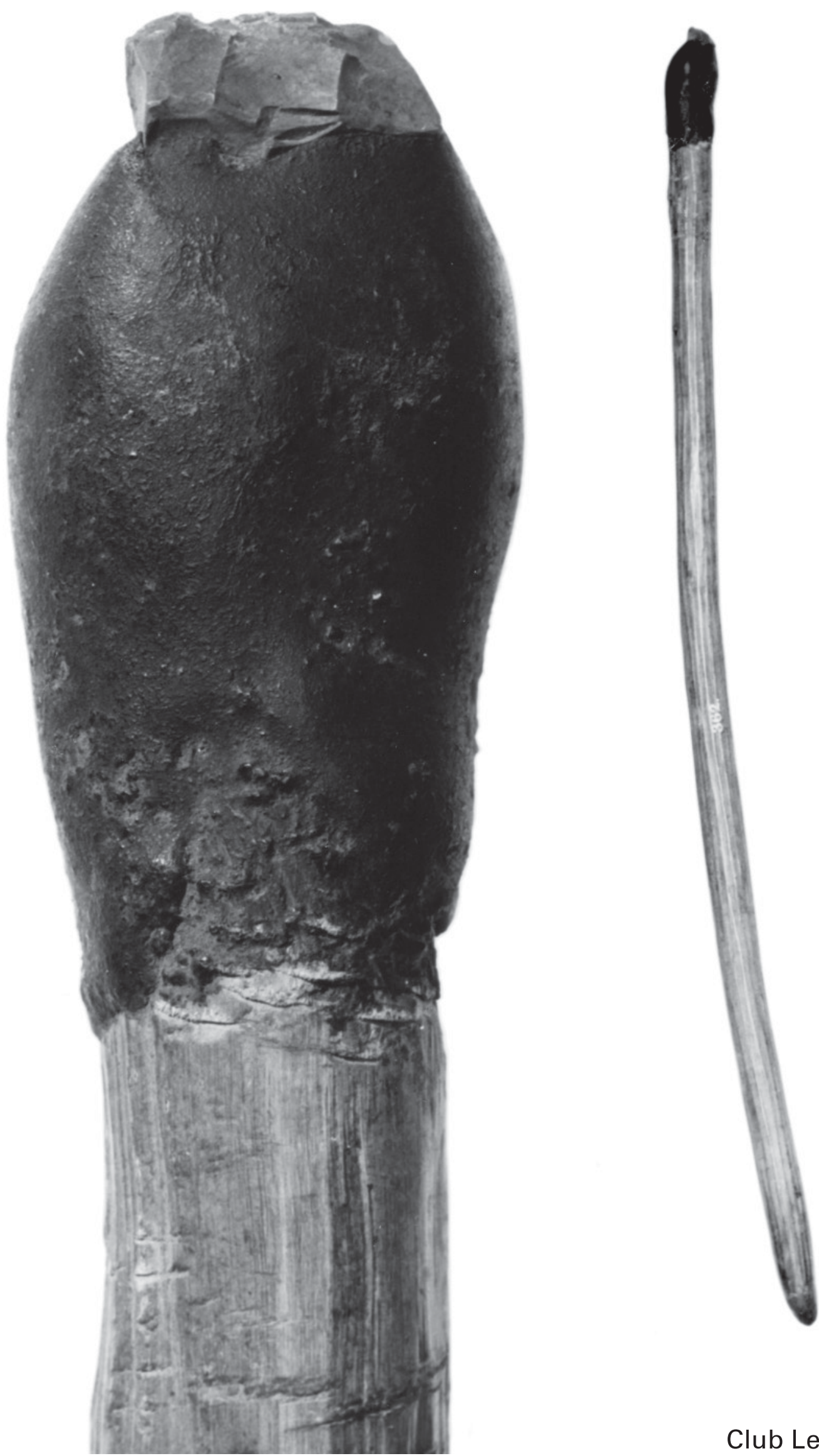

Club Length: $768 \mathrm{~mm}$

FIGURE 6 A South-West club, A00362, Anthropology Department collection, WA Museum. The stone adze, hafted with Xanthorrhoea resin, has retouch on the lateral margins. (Photos: Douglas Elford.) 
used in the South-West (Figure 6), rather than Triodia $s p$. resins or beeswax which are used elsewhere in the state. Grindstones are typically South-West and are small and dimpled.

\section{SUMMARY}

The location of sites in the Esperance region reflects a landscape used by small groups of foragers with high residential mobility. The majority of sites contain few artefacts and are small nodes of human presence mostly focused on granites or features where freshwater can be obtained and where biological diversity is greater. People favoured camp sites that afforded either protection from the south-west winds or commanding views over the surrounding landscape and were within $500-800 \mathrm{~m}$ of fresh water. There are only four sites with more than 1,000 artefacts, possibly locations of intra- or inter-group gatherings.

In the absence of a suite of dated sites it is not possible to examine changes in settlement patterns. In Cheetup, the one site that spans 13,000 years until the historic period, changes in discard rate clearly reflect alteration in human activities in the cave. The earliest occupation unit consists mainly of cooking hearths, while the more recent unit reflects a focus on resin preparation and hafting. The rate of establishment of new sites cannot be determined with any degree of accuracy. While Cheetup appears to mark the beginning of the human occupation of the current coastal regions by $13,000 \mathrm{BP}$, the absence of any indication of occupation prior to the late Holocene in the interior zone may reflect comparatively recent amelioration of local environmental conditions and attendant later occupation of this zone.

\section{MOBILITY AND RESOURCE STRUCTURES}

Just what then do these Esperance area artefact scatters represent? Ethnographic observations about radius of stone debitage from individual stone tool knappers, the areal extent of occupation sites and activity areas in relationship to group size and duration of site occupation, provide a framework for possible explanations about the nature of these local artefact scatters. Some 1,200 km north-east of the Esperance area, Hayden (1979: 165-166) recorded a $6 \mathrm{~m}$ radius of stone artefact debris around hearth and activity areas for individuals on two sites in the Gibson Desert. Ngarulurutja and Walukaritji were occupied respectively for one and three weeks, with total numbers of discarded stone being 114 and 94 pieces over areas of $79-113 \mathrm{~m}^{2}$. Over one to three week periods of occupation, family groups of between 6 to 12 people discarded from between 6 to 28 pieces of stone per person per week.

The hazards of basing estimates of population size on artefact numbers and numbers of sites have been discussed at great length in Australia (e.g. Dortch and Smith 2001). However, the consistency in size and distribution of artefact scatters in the region, in combination with ethnographic analogies, strongly suggests that those Esperance area sites with few artefacts, whether the latter are contemporaneous or not, are unlikely to represent major habitation sites and probably reflect occupation periods of short duration. Small numbers of artefacts spread over areas less than $20 \mathrm{~m}^{2}$ cannot represent the presence of large numbers of people. Major habitation sites or base camps either occupied by large groups for several weeks, or revisited over long periods of time, could be expected to have considerable numbers of discarded artefacts. Major habitation sites could also be expected to be reasonably extensive if occupied by more than a nuclear family at any one time, or to have reasonable artefact density if reoccupied.

The archaeological residue of small groups of people, staying for short terms at locations before moving on, and leaving a low artefact discard signal at habitation sites (O'Connor et al. 1993) is consistent with the low level, low extent and low density pattern of artefact discard in the Esperance region. These small archaeological sites are best explained as the reflection of small groups of people with high residential mobility (frequent relocation of the group's camp or residence). Kelly (1995: 118) explains the Binford proposition that residential mobility is typical of foragers, moving to their food resources, or mapping onto regional resources, obtaining immediate return. There are only four sites with more than 1,000 artefacts, all in the coastal zone. Compared to other sites, these have greater artefact frequencies, a wider range of lithic types (including some exotics), greater areal extent, and indications of use over longer periods. They are interpreted as foci of group, and perhaps inter-group, gatherings. Depending on the nature of the 'gathering', occupants need not necessarily focus on stone tool production, but one would expect these locations to have relative resource abundance to sustain larger groups, and to have other archaeological features (e.g. rock art, stone arrangements).

The trend towards increased sedentism and decreased mobility that has been identified elsewhere in Australia (Lourandos 1997) seems to be absent in the Esperance region, where people remain highly mobile foragers. Lourandos suggested that the move towards decreased mobility sometimes ran counter to environmental resource structures (1997: 305). In the Esperance region, by contrast, it seems that a continuing pattern of high residential mobility was maintained even in areas where resource structures could have supported decreased mobility. The answer to unlikely responses to environmental conditions might be found in socio- 


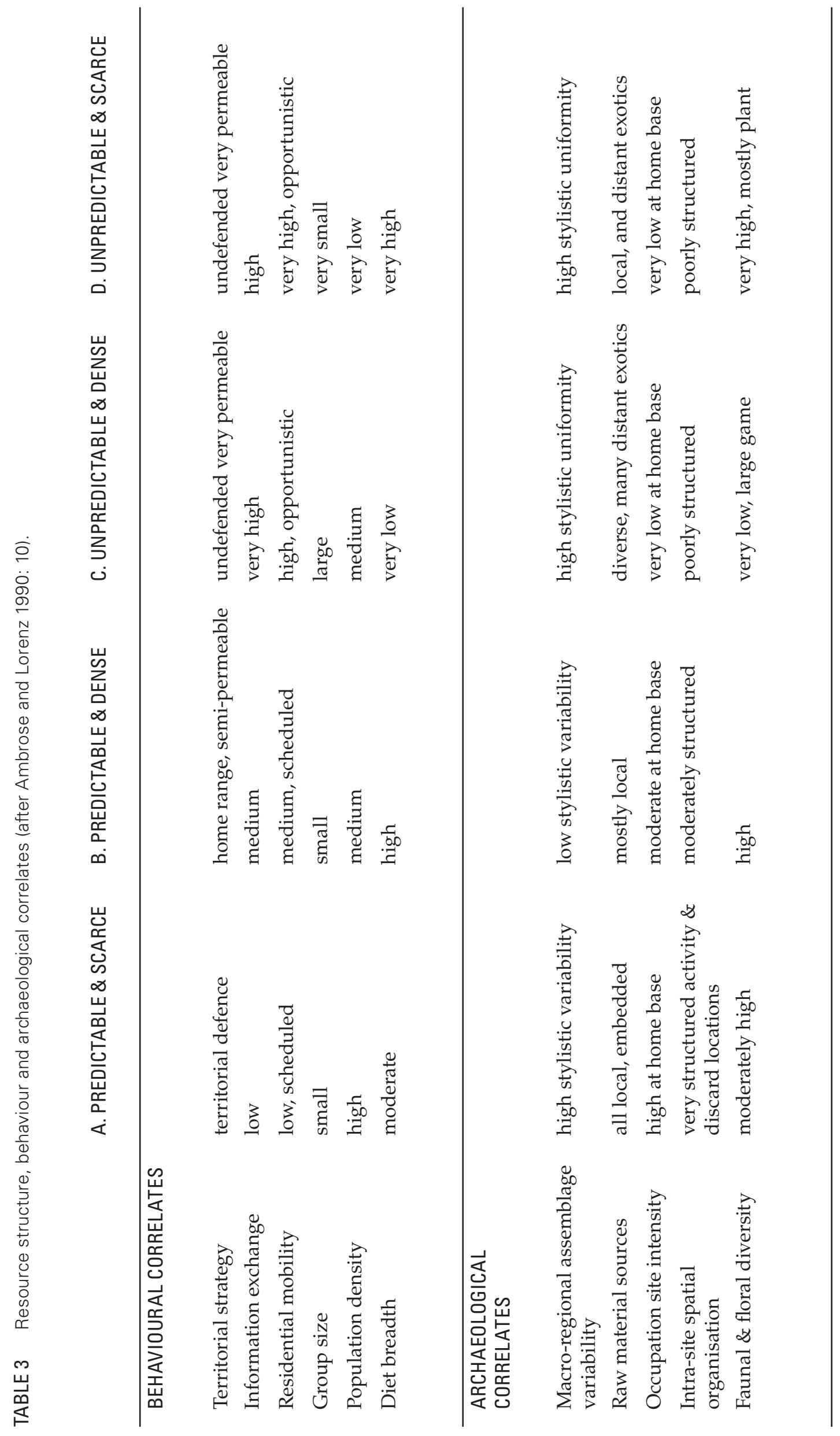


demographic environments, but people also appear to make cultural choices based on local resource structure - the spatial and temporal abundance and predictability of resources.

Ambrose and Lorenz (1990) have developed a useful model for considering resource structures (Table 3), based on earlier models of Winterhalder (1981). They identify four poles in a continuum of resource structure according to predictability and abundance of resources. I have considered the nature of the Esperance area local resource structure and expected behavioural correlates; the extent of overlap between expected and observed behaviour and the archaeological correlates these should have; and the degree of fit between local archaeological record and behaviour and resource structure. This information is drawn largely from my doctoral thesis (Smith 1993: 353-358) and summarised here.

\section{LOCAL RESOURCE STRUCTURE AND BEHAVIOURAL CORRELATES}

Water is abundant in the coastal zone, scarce in the interior, but predictable in both zones if rainfall patterns are monitored. Plants have predictable locations (both general and specific) but their abundance varies according to rainfall. Knowledge of their distribution again depends on monitoring rainfall patterns. Coastal species (including those found in estuaries) are moderately abundant and some are predictable, for example seal colonies, fish migratory patterns, fish in estuaries, shellfish, and nesting sea birds. Small mammals and reptiles are not overly abundant, but habitat preference is constant, and their general location is predictable. Some large mammals, for example the Western Grey Kangaroo (Macropus fuliginosus), are territorial, and have predictable morning and evening feeding patterns; other wallabies have a predictable range. Water birds are usually located in the coastal swamps, and emus can be targeted by monitoring the progress of one of their target foods Santalum acuminatum, or quandong. While emus occur in both zones, they are frequently targeted in the interior near quandong stands, for example, near Mt Ridley (Arthur Dimer, pers. comm.).

The apparent initial occupation of the region at 13,000 BP coincided with the end of a drier and colder period during which sand dunes were mobilised. At this stage shoreline advance and territorial contraction was fairly rapid. For example, Cheetup, which was about $80 \mathrm{~km}$ inland at 13,000 $\mathrm{BP}$, was only about $11 \mathrm{~km}$ from the shore by 10,000 BP. By 10,000 BP the current coastal zone should have already been subject to the predictable rainfall patterns of the Mediterranean regime and the interior subject to the unpredictable conditions which currently prevail (Beard 1990). By 7,000 BP, the granite peaks, which had formed part of the earlier extended coastal plain, had become islands, and the shoreline was about $8 \mathrm{~km}$ from Cheetup. Climatic conditions appear to have remained relatively stable over the last 5,000 or 6,000 years

The Esperance region today appears to have two different resource structures - predictable and scarce in the coastal zone, and unpredictable and scarce in the interior. One could expect behavioural correlates for the coastal zone to include territorial defence, low information exchange, low and scheduled residential mobility, small group size, high population density and moderate diet breadth. For the interior, behavioural correlates should be undefended and permeable territorial strategies, high information exchange, very high and opportunistic residential mobility, very small group size, very low population density and very high diet breadth. For the early period (i.e. the end of the Pleistocene) it is difficult to identify all the expected behavioural correlates of these resource structures. In both coastal and interior zones, however, residential mobility seems to have been high to very high, group size and population density both appear to have been low and diet breadth was apparently very high. Despite the distinct variation in resource structure between coast and interior, these are all behavioural correlates commensurate with an unpredictable and scarce resource structure.

The regional archaeological record also reflects what Ambrose and Lorenz's (1990) model posits as linked with an unpredictable and scarce resource structure, that is, with the conditions of the interior.

1. Macro-assemblage variability exhibits both high stylistic uniformity (D) and low stylistic variability (B).

2. Raw material (stone) sources are predominantly local with some exotics from outside the study area (D).

3. Occupation site intensity as identified by artefact numbers and areal extent of sites is very low at home base, in fact few 'home bases' can be identified (D).

4. Intra-site spatial organisation is poorly structured (D).

5. Faunal and floral diversity is high, and ethnographic evidence suggests this is particularly so of plants.

The inclusion of both marine and estuarine resources in the same subsistence base, despite the 'conflicting' values these have as companion foods with hinterland resources (cf. Dwyer 1988; O'Connor 1990), is accounted for by a link between unpredictable and scarce resource structure and high diet breadth. 


\section{CONCLUSION}

Since the resource structures are not uniform, why is there evident uniformity of ethnographically observed behaviours, and an archaeological record reflecting continuity of behaviour over several thousand years? It may be that, despite apparent relative predictability of the coastal zone, local occupants perceived it differently as unpredictable. It may on the other hand be that any difference in strategy is not represented archaeologically, or is represented very subtly. It could be, for example, that the absence of sites with more than 1,000 stone artefacts in the interior, compared with the coastal zone where several occur, is an index of a slight tendency towards decreased residential mobility in the coastal zone. There are indications of Late Holocene attempts to increase local resource predictability or 'extend their economic utility' (Bettinger 1987: 125), for example by capping gnamma holes (Figure 4), and constructing lizard habitats (Smith 1993: 246-252). The storage of Macrozamia kernels during the late Pleistocene is also evidence of attempts to increase resource predictability (cf. Kelly 1983: 292).

In summary, the dominant features of the region, apparently through the last 10,000 years at least, are small sites with few artefacts and confined horizontal distribution. Artefact assemblages are remarkably uniform and tools are made predominantly of local stone materials although some exotics also occur. These are a characteristic response to temporal and spatial unpredictability and shortage of resources. The maintenance of a behavioural system geared towards such environmental conditions, regardless of the apparent variation in actual resource structure, may reflect a specialised local cultural adaptation with an emphasis on risk minimisation (cf. Yellen 1986). There appears to be a highly mobile society in a semiarid and marginal environment making some slight effort to expand or control the resource base but not responding to ameliorating conditions or a broadened resource base by decreasing their residential mobility. Whether this type of response is true of other people living in semi-arid marginal environments and with what is essentially a resource poor coastline as well, or whether this is an entirely local response has not been tested at this stage. Diversified economic activities in different microenvironments are a normal response to climatic unpredictability (Kelly et al. 2005). Mobility may be a well-entrenched pattern constrained by social relations that would survive whatever the environmental regime. In his research in the King George Sound region about $400 \mathrm{~km}$ west of Esperance, Ferguson (1985: 53) identified 'casual but constant mobility' despite a relatively resource rich environment as a characteristic of local and west coast Nyungar society. The adoption of a similar highly mobile, extreme forager lifestyle in the Esperance area on the margins of the South-West culture bloc is suggestive of a particular South-West cultural phenomenon, one that is not obviously tightly tied to local resource structures. Whatever the initial impetus for a lifestyle that embraced high residential mobility, and despite conditions that didn't always make this a survival imperative, moving on seems to have been the preferred local lifestyle.

\section{ACKNOWLEDGEMENTS}

I should like to acknowledge the Aboriginal people of the Esperance region, many of whom have shared their knowledge with me over the years. Caroline Bird and an anonymous referee provided helpful comments on a draft of this paper.

\section{REFERENCES}

Ambrose, S.H. and Lorenz, K.G. (1990). Social and eological models of the Middle Stone Age in southern Africa (pp. 3-33). In: Mellars, P. (ed.), The emergence of modern humans. Edinburgh University Press: Edinburgh.

Beard, J.S. (1973). The vegetation of the Esperance and Malcolm areas, Western Australia 1: 250,000 Series. Vegmap Publications: Perth.

Beard, J.S. (1990). Plant life of Western Australia. Kangaroo Press: Kenshurst.

Berndt, R.M. (1979). Aborigines of the South-west (pp. 81-89). In: Berndt, R.M. and C.H. (eds), Aborigines of the west, their past and present. University of Western Australia Press: Nedlands.

Bettinger, R.L. (1987). Archaeological approaches to hunter-gatherers. Annual Review of Anthropology 16: 121-142.

Bird, C.F.M. (1985). Prehistoric lithic resource utilisation: a case study from the southwest of Western Australia. PhD thesis, University of Western Australia: Nedlands.

Bowdler, S. (2000). Australian hunter-gatherer settlement systems: can we identify directional change over time? Paper presented at 65th Annual Meeting of the Society for American Archaeology, Philadelphia, USA, March 2000. Accessed July 22, 2005 from: http: / / www.archaeology.arts.uwa.edu.au/staff / bowdler__research_interests / saa_2000_paper_ australian_huntergatherer_settelment_systems_can_we_identify_direcitonal_change_over_time/

Bowdler, S. and O'Connor, S. (1991). The dating of the Australian Small Tool Tradition, with new evidence from the Kimberley, WA. Australian Aboriginal Studies 1991/1: 53-62.

Bowler, J.M. (1976). Aridity in Australia: age, origin and expression in aeolian landforms and sediments. Earth Science Review 12: 279-310.

Dortch, C.E. (1975). Geometric microliths from a dated archaeological deposit near Northcliffe, Western Australia. Journal of the Royal Society of Western Australia 58: 59-63.

Dortch, C.E. (2000). Past Aboriginal hunter-gatherer economy and territorial organization in coastal districts of Western Australia's lower South-west. PhD thesis, University of Western Australia: Nedlands. 
Dortch, C.E. (2002). Modelling past Aboriginal huntergatherer socio-economic and territorial organisation in Western Australia's lower South-west. Archaeology in Oceania 37: 1-21.

Dortch, C.E. and Morse, K. (1984). Prehistoric stone artefacts on some offshore islands in Western Australia. Australian Archaeology 19: 31-47.

Dortch, C.E. and Smith, M.V. (2001). Grand hypotheses: palaeodemographic modelling in Western Australia's South-west. Archaeology in Oceania 36: 34-45.

Dwyer, P.D. (1988). Companion foods, schedules and archaeology (pp. 148-155). In: Meehan, B. and Jones, R. (eds), Archaeology with ethnography: an Australian perspective. Department of Prehistory, Research School of Pacific Studies, Australian National University: Canberra.

Ferguson, W.C. (1980). Fossiliferous chert in southwestern Australia after the Holocene Transgression: a behavioural hypothesis. The Artefact 5: 155-169.

Ferguson, W.C. (1985). A mid Holocene depopulation of the Australian southwest. PhD thesis, Australian National University: Canberra.

Glover, J.E. (1975a). The petrology and probable stratigraphic signature of aboriginal artefacts from part of south-western Australia. Journal of the Royal Society of Western Australia 58: 75-85.

Glover, J.E. (1975b). Aboriginal chert artefacts, probably from quarries on the continental shelf, W.A. Search 6: 392-394.

Hallam, S.J. (1975). Fire and hearth: a study of Aboriginal usage and European usurpation in south-western Australia. Australian Institute of Aboriginal Studies: Canberra.

Hallam, S.J. (1983). Sorts of sites: mobility, group fluctuation and the genesis of artefact scatters. Paper presented at ANZAAS conference, Perth.

Hallam, S.J. (1986a). Prehistoric aboriginal populations on the Swan Coastal Plain, Western Australia. Unpublished Report to the Australian Research Grants Scheme.

Hallam, S.J. (1986b). Yams, alluvium and 'villages' on the west coastal plain (pp. 116-132). In: Ward, G. (ed.), Archaeology at ANZAAS, Canberra: papers delivered to the 54th ANZAAS Congress, 1984. Canberra Archaeological Society: Canberra.

Hayden, B. (1979). Palaeolithic reflections. lithic technology and ethnographic excavations among Australian Aborigines. Australian Institute of Aboriginal Studies: Canberra.

Hexter, J.H. (1971). The history primer. Basic Books: New York.

Hiscock, P. and Attenbrow, V. (1998). Early Holocene backed artefacts from Australia. Archaeology in Oceania 33: 49-62.

Hiscock, P. and Veth, P.M. (1991). Change in the Australian desert culture: a reanalysis of tulas from Puntutjarpa Rockshelter. World Archaeology 22: 332345.

Huchet, B.M.J. (1991). Theories and Australian prehistory: the last three decades. Australian Archaeology 33: $44-51$.

Jarvis, N. (ed.) (1986). Western Australia: an atlas of human endeavour. Department of Lands and Survey and Western Australian Education Department: Perth.
Kelly, R.L. (1983). Hunter-gatherer mobility strategies. Journal of Anthropological Research 39: 277-306.

Kelly, R.L. (1995). The foraging spectrum; diversity in hunter-gatherer lifeways. Smithsonian Institution Press: Washington, D.C.

Kelly, R.L., Poyer, L. and Tucker, B. (2005). An ethnoarchaeological study of mobility, architectural investment, and food sharing among Madagascar's Mikea. American Anthropology 107: 403-416.

Lourandos, H. (1983). Intensification: a late PleistoceneHolocene archaeological sequence from southwestern Victoria. Archaeology in Oceania 18: 81-94.

Lourandos, H. (1997). Continent of hunter-gatherers: new perspectives in Australian prehistory. Cambridge University Press: Melbourne.

Nelson, M.C. (1991). The study of technological organization. Archaeological Method and Theory 3: 57-100.

O'Connor, S. (1990). 30,000 years in the Kimberley: a prehistory of the islands of the Buccaneer Archipelago and adjacent mainland, West Kimberley, Western Australia. PhD thesis, University of Western Australia: Perth.

O'Connor, S., Veth, P. and Hubbard, N.N. (1993). Changing interpretations of postglacial human subsistence and demography in Sahul (pp. 95-105). In: Smith, M.A., Spriggs, M. and Fankhauser, B. (eds), Sahul in review: Pleistocene archaeology in Australia, New Guinea and Island Melanesia. Occasional Papers in Prehistory 24. Department of Prehistory, Research School of Pacific Studies, Australian National University: Canberra.

Schwede, M. (1990). Quartz, the multifaceted stone: a regional prehistory of the Helena River Valley on the Swan Coastal Plain of southwestern Australia. PhD thesis, University of Western Australia: Nedlands.

Smith, M.V. (1993). Recherche a l'Esperance: a prehistory of the Esperance region of south-western Australia. PhD thesis, University of Western Australia: Nedlands.

Stafford Smith, D.M. and Morton, S.R. (1990). A framework for the ecology of arid Australia. Journal of Arid Environments 18: 255-278.

Veth, P.M. (1989). The prehistory of the Sandy Deserts: spatial and temporal variation in settlement and subsistence behaviour within the arid zone of Australia. PhD thesis, University of Western Australia: Nedlands.

Veth, P. and Moore, P. (1989). Report of an archaeological and ethnographic survey in the South Coast Highway, Stokes Inlet Road to Young River Bridge, West of Esperance, WA. Unpublished report for the Main Roads Department, Western Australia.

Winterhalder, B. (1981). Optimal foraging strategies and hunter-gatherer research: theories and models (pp. 13-35). In: Winterhalder, B. and Smith, E.A. (eds), hunter-gatherer foraging strategies: ethnographic and archaeological analysis. University of Chicago Press: Chicago.

Wyrwoll, K.H. (1979). Late quaternary climates of Western Australia. Journal of the Royal Society of Western Australia 62: 129-142.

Yellen, J.E. (1986). Optimization and risk in human foraging strategies. Journal of Human Evolution 15: 733-750.

MANUSCRIPT RECEIVED DECEMBER 2005: ACCEPTED NOVEMBER 2008 